\title{
Educational Inclusion and Social Interaction: A Literature Review
}

\author{
Larissa Rodrigues Rosa ${ }^{* 1}$ \\ Orcid.org/0000-0002-4962-280X \\ Aline Beckmann Menezes ${ }^{1}$ \\ Orcid.org/0000-0002-3136-3707
}

${ }^{1}$ Universade Federal do Pará, Belém, PA, Brasil

\begin{abstract}
Social interactions between disabled children and their peers are not only important to their development of social competence, but may also be indicative of the extent of educational inclusion at the children's school. The aim of this study was to perform a literature review of Brazilian articles on the topic of educational inclusion and social interactions involving children with disabilities. A total of 465 articles published between 2007 and 2017 were obtained from the Scientific Electronic Library Online (SciELO) and the Brazilian Association for the Improvement of Higher Education Personnel (CAPES) databases. The keywords used inclusion, educational inclusion, social interaction, and socialization. After the exclusion criteria were applied, there remained 26 articles and empirical studies published in Portuguese on the topic of social interaction among children with and without disabilities in schools offering educational inclusion programs. Most of the results in these articles described cases of social exclusion within these schools; in these cases, interactions between disabled children and their peers were rare or nonexistent, and the faculty and staff exhibited some distrust in the disabled students' abilities to learn and develop academically. The review also revealed the need for empirical intervention studies that may ultimately produce proposals for changes in these policies and situations.
\end{abstract}

Keywords: Educational inclusion, social interaction, disability.

\section{Inclusão Escolar e Interação Social: Uma Revisão de Literatura}

\section{Resumo}

As interações sociais entre crianças com deficiência e seus pares podem ser um indicativo do grau de inclusão presente em uma escola, além de serem importantes no desenvolvimento da competência social. Este estudo teve como objetivo fazer uma revisão de literatura nacional brasileira sobre artigos científicos relacionados à temática da inclusão e interação social de alunos com deficiência. Foram localizados 465

* Mailing address: Av. Maranhão, Q-1, C-1, Águas Lindas, Ananindeua - PA, Brazil 67118-250. E-mail: larissarosa93@gmail.com

The research is partially financed by a Master's degree scholarship from the Brazilian Association for the Improvement of Higher Education Personnel (CAPES) and also received support of Pró-Reitoria de Pesquisa e Pós-Graduação/Universidade Federal do Pará (PROPESP/UFPA). We would like to thank Dr. Marcus Bentes de Carvalho Neto for his collaboration with this study. 
estudos nas bases SciELO e Portal de Periódicos da CAPES publicados entre 2007 e 2017, utilizando os descritores inclusão e interação social, inclusão escolar e socialização. Após aplicação dos critérios de exclusão foram selecionados 26 artigos em português e empíricos que abordavam a interação social de crianças com e sem deficiência na escola inclusiva. Como resultados pode-se pontuar que a maioria dos artigos descreve cenários de exclusão na inclusão, nos quais são poucas ou inexistentes as interações da criança com deficiência e seus pares, e nos quais os profissionais da escola mostram descrença na capacidade dessas crianças aprenderem e se desenvolverem academicamente. Aponta-se ainda a necessidade do desenvolvimento de pesquisas empíricas de intervenção, que construam propostas de mudança na realidade observada.

Palavras-chave: Inclusão escolar, interação social, deficiência.

\section{Inclusión Escolar e Interacción Social: Una Revisión de Literatura}

\section{Resumen}

Las interacciones sociales entre niños con discapacidad y sus pares pueden ser un indicativo del grado de inclusión presente en una escuela, además de ser importantes en el desarrollo de la competencia social. Este estudio tuvo como objetivo hacer una revisión de literatura nacional brasileña sobre artículos científicos relacionados a la temática de la inclusión e interacción social de alumnos con discapacidad. Se localizaron 465 estudios en las bases SciELO y Portal de Periódicos de la CAPES publicados entre 2007 y 2017, utilizando los descriptores inclusión e interacción social, inclusión escolar y socialización. Después de aplicar los criterios de exclusión fueron seleccionados 26 artículos en portugués y empírica que abordó la interacción social de los niños con y sin discapacidad en la escuela inclusiva. Como resultados se puede puntuar que la mayoría de los artículos describen escenarios de exclusión en la inclusión, en los que son pocas o inexistentes las interacciones del niño con discapacidad y sus pares, y en los que los profesionales de la escuela muestran incredulidad en la capacidad de estos niños para aprender y desarrollar académicamente. Se apunta también la necesidad del desarrollo de investigaciones empíricas de intervención, que construyan propuestas de cambio en la realidad observada.

Palabras clave: Inclusión escolar, interacción social, discapacidad.

In Brazil, educational inclusion has been influenced by a variety of global policies and documents, including the World Declaration on Education for All from the World Conference on Education for All in Jomtien, Thailand (United Nations Educational, Scientific and Cultural Organization [UNESCO], 1990) and the Salamanca Statement and Framework for Action (UNESCO, 1994). Though the Brazilian Constitution of 1998 outlined access to special education as part of regular schooling, it has only been through other publications, laws, and decrees that the concept of inclusion has taken shape. The Brazilian Inclusion of People with Disabilities Act (known locally as the Lei Brasileira de Inclusão) and the Guidelines and Foundations of National Education (Lei de Diretrizes e Bases da Educação Nacional) provide the main legal infrastructure for the establishment of educational inclusion as a right granted to people with disabilities.

The academic census performed in Brazil in 2007 by the Anísio Teixeira Institute for Educational Research and Studies (INEP, 2008) was the first to distinguish between student enrollment in special classes and exclusive schools versus in common (inclusive) classrooms. This distinction revealed a decrease in the number of disabled students enrolled in specialized institutions and an increase in their enrollment in regular classrooms in the decade in question (Figure 1). 


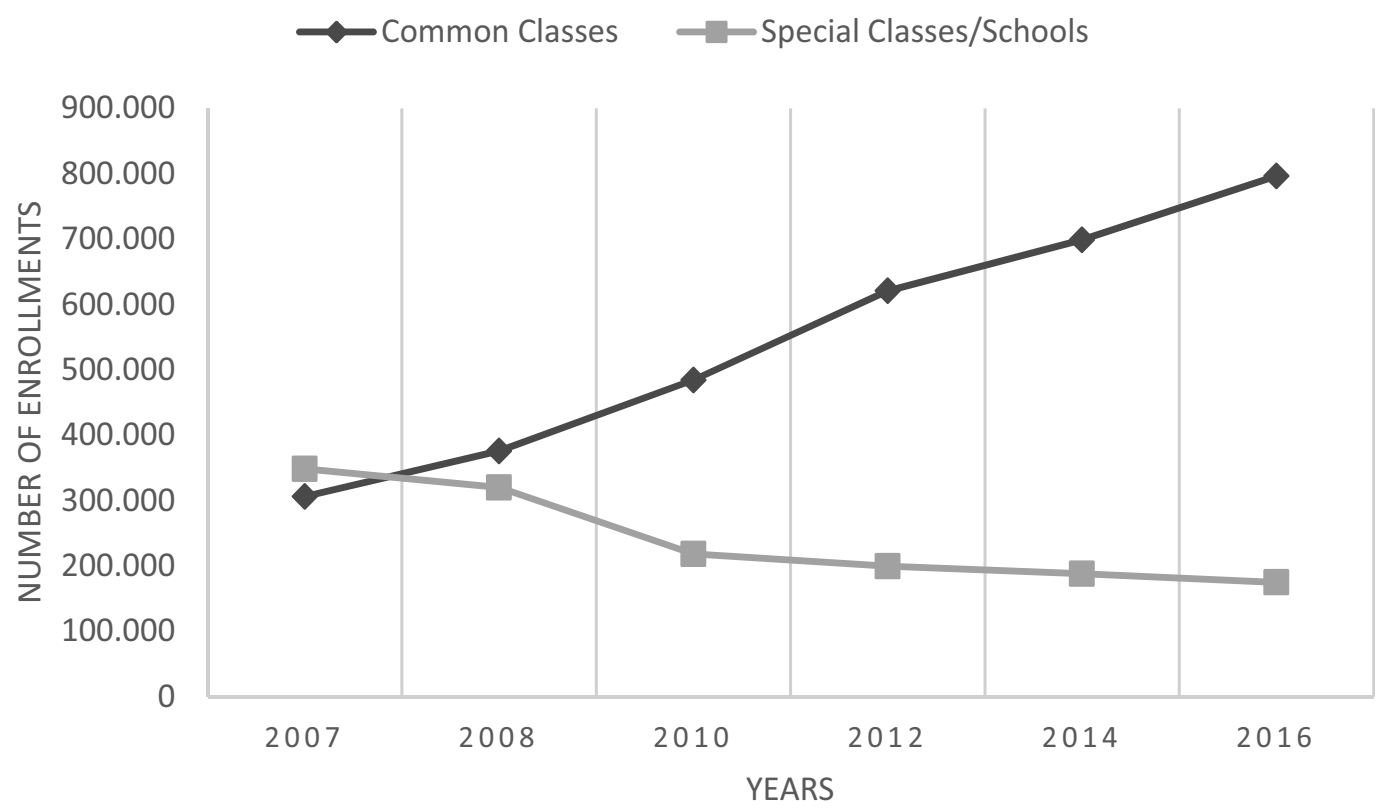

Figure 1. Increase in the number of enrollments of students with disabilities in Brazil from 2007 to 2016. Note. Created by the authors based on data from the Brazilian Academic Census 2007 to 2016 (INEP, 2008, 2014; INEP \& Brazilian Ministry of Education and Culture [MEC], 2017; MEC, 2014).

Based on the data provided by INEP, it is clear that the presence of students with disabilities in the general education classroom has become more frequent over time; however, rates of enrollment are not a reliable indicator of the extent of educational inclusion in a given environment. Segregation and exclusion may occur in institutions or environments that appear to offer inclusive education. Exclusion within inclusive education occurs when disabled students do not participate in activities (academic or otherwise) proposed by teachers or the school, or when the academic adaptations proposed for the students do not reflect their true needs or abilities. It also occurs when the learning environment is one of constant surveillance and overprotectiveness from teachers, staff, or students.

In this context, the main barriers to involving students with disabilities are the way in which their differences are understood by society, the belief that people with disabilities are less capable of doing things, and difficulty in actively participating in society (Mendes, 2015). Therefore, understanding how students with and without disabilities interact in general education, developing and testing intervention strategies meant to reduce negative interactions, and increasing or instituting positive social interactions are extremely relevant to the effective inclusion of people with disabilities.

According to O'Connor (1969, 1972), social interactions are understood as reciprocal responses to third party behaviors. Ferreira (2017) emphasizes that social interaction is the first stage in the development of interpersonal relationships and describes social interaction as specific and brief. Even if these interactions are short, it is through them that people experience reciprocal relations, various interactions involving exchanges in affection, and relational networks (Ferreira, 2017). Studies have mentioned that relationships between children with and without disabilities consist of few interactions, which renders the development of friendship unfeasible (Batista \& Enumo, 2004; Ferreira, 2017; Ribeiro, 2016).

Whether children are typical or not, a lack of significant relationships with peers is detrimental to a child's development, since these relationships are directly correlated with the acquisition of socially accepted behaviors and improved social skills (Del Prette \& Del Prette, 2005). According to Rosin-Pinola and Del Prette 
(2014), social skills are a determining factor in children's adjustment to school, both in the academic sense and in terms of interpersonal relationships. This affirmation is based on the associations between social skills and the facilitation of learning (Del Prette, Del Prette, De Oliveira, Gresham, \& Vance, 2012; DiPerna, 2006) and between the deficit in these skills and behavior problems (Bandeira, Del Prette, Del Prette, \& Magalhães, 2009; DiPerna, 2006).

For this reason, the social relationships encouraged by educational inclusion programs and by disabled children's overall experiences in school are extremely relevant. The quantity and quality of social interactions between children with and without disabilities may be indicators of the degree of educational inclusion in a given institution, or, in other words, the extent to which disabled children are included in a given environment (Dias, Sousa, Gonçalves, Flores, \& Pérez, 2016; Santo \& Santos, 2016). Therefore, it is relevant to understand not only how interactions between children with and without disabilities tend to occur in the context of general education, but also which types of interventions have been shown to be effective in promoting these interactions.

The relevance of this topic, in addition to the lack of other literature reviews considering Brazilian research on the socialization of students with disabilities in the context of general education, reflects the importance of this study. The main objective of this research was to determine what Brazilian researchers have studied regarding social interactions in the context of academic accessibility, with a focus on which interventions have been reported as effective in promoting social interactions between students with and without disabilities.

\section{Methods}

A survey of Brazilian empirical studies addressing social interactions between children with and without disabilities was performed in May and June of 2017 using the databases provided by the Scientific Electronic Library Online (SciELO) and the Brazilian Association for the Improvement of Higher Education Personnel (CAPES). The search was guided by the following question: "What has been reported in research on social interactions between children with and without disabilities in general education programs?" The keywords used in the search were in Portuguese and in the singular form. Searches were performed using the keywords in different combinations. The Portuguese keywords used were inclusão AND interação social (inclusion AND social interaction), inclusão escolar AND interação social (educational inclusion AND social interaction), inclusão AND socialização (inclusion and socialization), and inclusão escolar AND socialização (educational inclusion and socialization). These descriptors were chosen because they are more comprehensive, and, therefore, were likely to produce a larger number of results.

Next, publications that addressed the subject were selected based on their titles and abstracts. The first inclusion criterion was defined as em-pirical articles addressing interactions between students with and without disabilities in general basic education classrooms as their main topic. Another inclusion criterion was the year of publication; since the Brazilian census data considered herein began to distinguish between disabled student enrollment in special classes versus general education classrooms in 2007, and there had been an increase in disabled student enrollment in general education classrooms in the decade, articles published between 2007 and 2017 were selected. The next step was the exclusion of duplicates and other publications that met the exclusion criteria. Books, theses, dis-sertations, reviews, and editorials were excluded, as well as publications in which the main topic of research was not, in fact, social interaction in the context of educational inclusion programs. In addition, theoretical publications were excluded, even if they reported reflections on socialization in schools offering educational inclusion.

As shown in Figure 2, 465 publications were obtained, though 376 were not focused on the issue of educational inclusion and social 


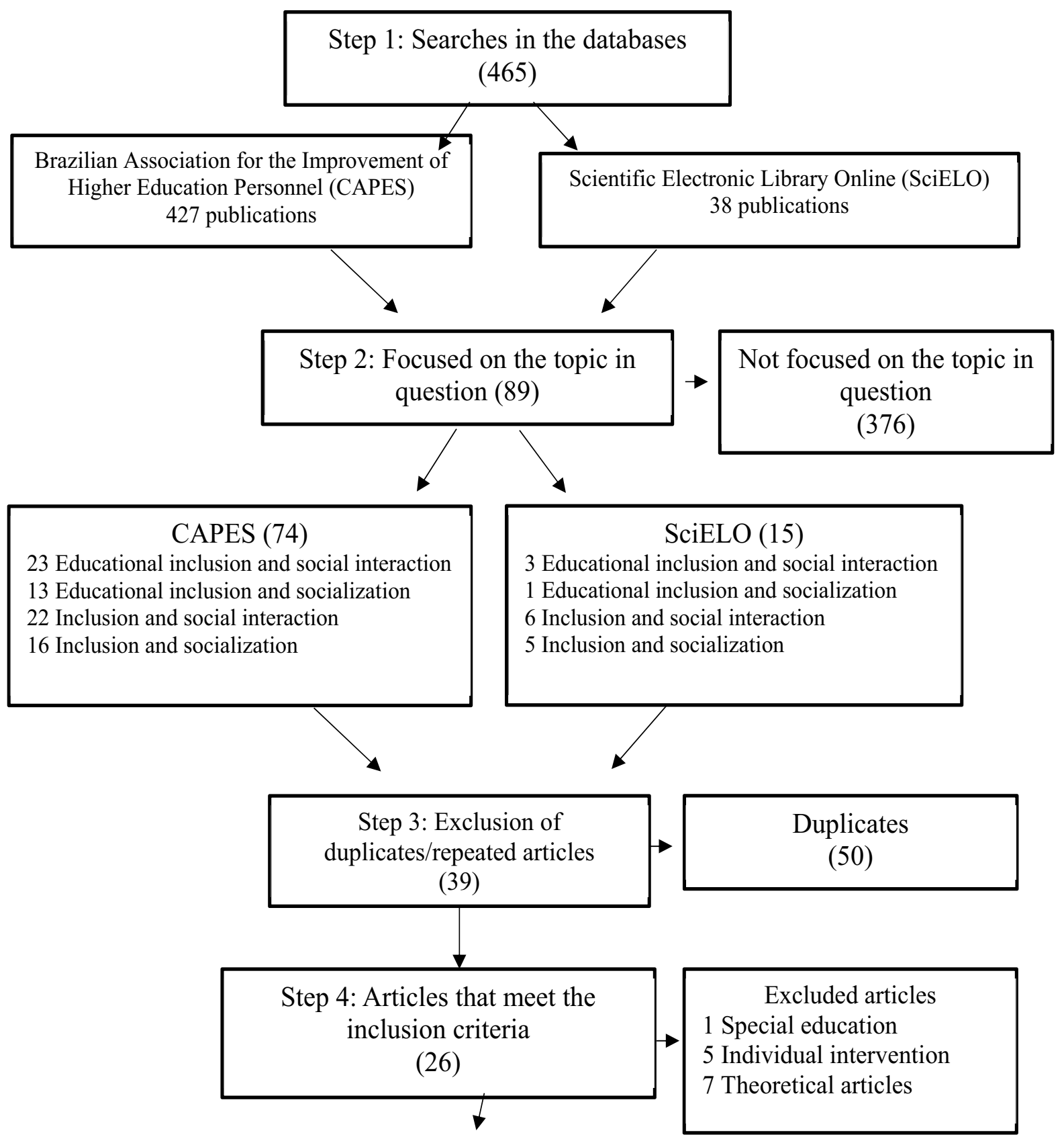

Final selection: 26 articles in total

Figure 2. Procedure used in the selection of articles.

interaction among peers. Of the 89 articles that remained, 50 were excluded because they were duplicates and 13 were excluded because they focused on the interaction between students with disabilities in specialized institutions (1), reported on individualized care performed outside general education (5), or were theoretical articles (7). Thus, 26 articles were considered in total.

\section{Results and Discussion}

The analysis of the articles will be presented using the following categories: General characteristics; Social interactions between students with and without disabilities; Interventions reported. 


\section{General Characteristics}

Table 1 presents a summary of the field of study, the level of education, the type of disability, the participants, and the region in Brazil described in each article collected.

Table 1

General Characteristics of the Articles Surveyed

\begin{tabular}{|c|c|c|c|c|c|c|c|}
\hline 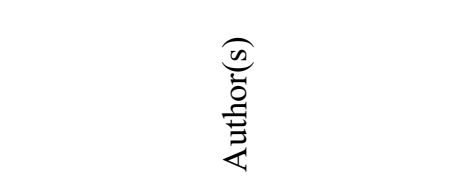 & 気 & 点点 & $\frac{\partial}{\frac{\partial}{2}}$ & 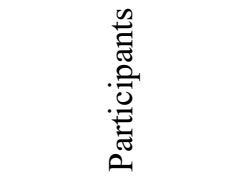 & 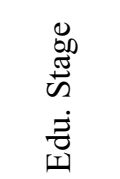 & 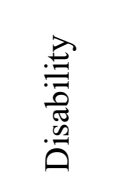 & 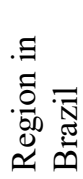 \\
\hline Gomes \& Rey & 2007 & Survey & Psych & Tch \& Adm & ES & NR & SE \\
\hline Laplane \& Batista & 2008 & Survey & Ed & SwD & ES & VI & SE \\
\hline Teixeira \& Kubo & 2008 & Survey & Psych & SwD e TS & ES & DS & $\mathrm{S}$ \\
\hline Anhão, Pfeifer, \& Santos & 2010 & Survey & Med & SwD e TS & $\mathrm{ECE}$ & DS & SE \\
\hline $\begin{array}{l}\text { Ferreira, Ferreira, } \\
\& \text { Oliveira }\end{array}$ & 2010 & Case Study & Ed & SwD & NR & DS & $\mathrm{N}$ \\
\hline Gomes \& Mendes & 2010 & Survey & Ed & Tch, SwD, \& TS & NR & ASD & SE \\
\hline $\begin{array}{l}\text { Nascimento, de Moura Scapim, } \\
\text { \& Silveira }\end{array}$ & 2010 & $\begin{array}{c}\text { Action } \\
\text { Research }\end{array}$ & Psych & SwD \& TS & ES & DS & SE \\
\hline Vitta, Vitta, \& Monteiro & 2010 & Survey & OT, ST, \& Ed & Tch & $\mathrm{ECE}$ & NR & $\mathrm{SE}$ \\
\hline Mattos \& Nuernberg & 2011 & Experimental & Psych & SwD \& TS & $\mathrm{ECE}$ & ASD & $\mathrm{S}$ \\
\hline Höher Camargo \& Bosa & 2012 & Case Study & Psych & SwD \& TS & $\mathrm{ECE}$ & ASD & S \\
\hline Leandro, Costa, \& Aquino & 2012 & Biography & $\mathrm{Ed}$ & SwD & HS & $\mathrm{HI}$ & NE \\
\hline $\begin{array}{l}\text { Souza, Bezerra, Bezerra, do } \\
\text { Nascimento Costa, \& Nozu }\end{array}$ & 2012 & Survey & Ed & TA & NR & NR & $\mathrm{CW}$ \\
\hline Chagas \& Dias & 2014 & Survey & $\mathrm{Ed}$ & Tch & $\mathrm{ECE}$ & NR & NE \\
\hline $\begin{array}{l}\text { Lemos, Salomão, } \\
\text { \& Agripino-Ramos }\end{array}$ & 2014 & $\begin{array}{c}\text { Field } \\
\text { Research }\end{array}$ & Psych & $\begin{array}{l}\text { Tch, SwD, } \\
\quad \& \mathrm{TS}\end{array}$ & ECE & ASD & $\mathrm{NE}$ \\
\hline $\begin{array}{l}\text { Misquiatti, Brito, dos Santos } \\
\text { Ceron, Piassi Carboni, } \\
\text { \& Olivati }\end{array}$ & 2014 & Experimental & ST & Tch & ES & ASD & $\mathrm{SE}$ \\
\hline Picolini \& Maximino & 2014 & Experimental & Den & TS & ES & NR & SE \\
\hline Torres \& Vieira & 2014 & Survey & Den & SwD & HS & $\begin{array}{l}\text { PD, VI } \\
\text { e HI }\end{array}$ & $\mathrm{NE}$ \\
\hline Brito & 2015 & Case Study & $\mathrm{Ed}$ & Tch, SwD, \& TS & $\mathrm{ECE}$ & ASD & $\mathrm{CW}$ \\
\hline Bruno \& Lima & 2015 & Action Research & $\mathrm{Ed}$ & $\begin{array}{l}\text { Par, Tch, SwD, } \\
\quad \& \mathrm{TS}\end{array}$ & NR & $\mathrm{HI}$ & CW \\
\hline Carvalho \& Nascimento & 2015 & Field Research & Psych & Therp & ECE & ASD & NE \\
\hline $\begin{array}{l}\text { Angnes, Morás, Klozovski, } \\
\text { \& Reali }\end{array}$ & 2016 & Case Study & N.I. & $\begin{array}{l}\text { Adm, SwD, } \\
\text { \& TS }\end{array}$ & $\begin{array}{l}\text { ES, HS } \\
\text { e VE }\end{array}$ & HI & $\mathrm{S}$ \\
\hline Campos \& Glat & 2016 & Action Research & Ed & Tch, SwD, \& TS & $\mathrm{ECE}$ & DS & $\mathrm{NE}$ \\
\hline
\end{tabular}




\begin{tabular}{lccccccc}
$\begin{array}{l}\text { Lemos, Salomão, Aquino, } \\
\text { \& Agripino-Ramos }\end{array}$ & 2016 & Survey & Psych & Tch \& Par & ECE & ASD & NE \\
Oliva & 2016 & Case Study & Psych & Tch, SwD, \& TS & ES & VI & SE \\
$\begin{array}{l}\text { Silva, Cabral, \& Martins } \\
\text { Souza, Silva, França-Freitas, \& } \\
\text { Gatto }\end{array}$ & 2016 & Survey & Ed & Tch & ES & NR & CW \\
\hline
\end{tabular}

Note. Key: Psych-Psychology; Ed-Education; Den-Dentistry; F-Physical Therapy; ST-Speech Therapy; OT-Occupational Therapy; Med-Medicine; SwD-Student with a disability; TS-Typical student; Tch-Teachers; Adm-Administrators; TATeachers' Aide; Therp-Therapeutic Assistant; Par-Parents; Edu. Stage-Educational Stage; ECE-Early Childhood Education; ES-Elementary School; HS-High School; VE-Vocational Education; HI-Hearing Impairment; PD-Physical Disability; VIVisual Impairment; DS-Down Syndrome; ASD-Autism Spectrum Disorder; NR-Not Reported; N-North; NE-Northeast; SSul; SE-Southeast; CW-Center-West.

The 26 articles collected were categorized into the following types of studies according to the classification provided by Garces (2010): surveys (11), case studies (7), field research (2), ethnographic studies (1), experimental studies (3), and action research (2). Thus, $81 \%$ of the articles (i.e., 22 publications) sought to describe a specific situation involving educational inclusion. Only five (19\%) articles attempted to provide possible interventions to promote interactions between students with and without disabilities (the three experimental studies and two publications involving action research).

The academic field of study was also considered. Forty percent were from the field of education and $40 \%$ were from psychology, while the remaining $20 \%$ were divided among the fields of dentistry (2), speech therapy (1), and medicine (1); one publication was an interdisciplinary study with authors from the fields of occupational therapy, physical therapy, and special education (1), and one paper did not define the field of study (1). Despite the predominance of studies performed by researchers in the fields of psychology and education, the diversity of the researchers' fields reflects the recognition of the importance of these interactions both for educational inclusion and for social development as a whole. Interdisciplinarity in the school was initially proposed specifically for the classroom; however, this understanding has reached the school as a whole (Garcia, 2012), including the role of psychology professionals in this space (Dias, Patias, \& Abaid, 2014).
In terms of the target group studied, nine articles investigated inclusion in early childhood education, nine articles addressed inclusion in elementary schools, and two other articles considered children in both early childhood education and elementary schools. More specifically, $69 \%$ of the publications focused on the initial years of basic education, a period that, according to Baer and Wolf (1970), is important in terms of engaging students in school activities and developing interpersonal relationships with peers in the following years.

The type of disability researched was also considered. Thirty-one percent of the studies addressed interactions involving children with an autism spectrum disorder (ASD); 23\% focused on children with Down syndrome (DS); $11 \%$ considered visually impaired children; $8 \%$ discussed children with hearing impairments; $4 \%$ focused on physical, visual, and hearing impairments; and $23 \%$ did not mention any specific disability. Most publications focused on ASDs, a finding which reflects the increasing interest in these disorders in the last decade. Between 2010 and 2012 (Gomes \& Mendes, 2010; Höher Camargo \& Bosa, 2012; Mattos \& Nuernberg, 2011), there was one publication per year on this topic; meanwhile, in 2014 and 2015, there were two publications each year (Brito, 2015; Carvalho \& Nascimento, 2015; Lemos et al., 2014; Misquiatti et al., 2014), and there was again a single publication in 2016 (Lemos et al., 2016). This increase in research may be related to Brazilian Law No. 12,764, from December 
2012, also known as the Berenice Piana Law, which is a legal framework providing the protection of the rights of people with ASDs, including the right to education.

It was also identified that the number of studies involving only students is higher than the amount of research done with other people involved in schools - four studies regarded students with disabilities, six involved disabled and non-disabled students, and one investigated non-disabled students' attitudes toward people with genetic syndromes. Therefore, a total of $38 \%$ of the studies considered in this review directly involved students. Meanwhile, 35\% of the publications considered teachers and caregivers, and $27 \%$ focused on caregivers, teachers, and students. The insertion of educational professionals as participants in research allows for an understanding of accessibility as a phenomenon that affects the school community as a whole - one that is not restricted to the disabled students alone.

In terms of geographic region, $35 \%$ of the surveys were performed in the southeastern region of Brazil and 31\% were performed in the northeastern region of the country; these two regions were the most frequently represented. The central-western region and southern region of Brazil are each represented in $15 \%$ of the articles, while only $4 \%$ of the studies addressed the northern region of the country. Though most of the studies were performed in the southeastern region, all regions of the country were represented in the literature.

\section{Social Interactions between Students with and without Disabilities}

As stated previously, $81 \%$ of the publications were characterized as descriptive, which means that they sought to address aspects of the inclusion process in a given context. Table 2 shows the authors, year, topic, and objectives of each study. It also lists whether there were positive social interactions between students with disabilities and their peers.

Only $38 \%$ of the studies sought to investigate the social interactions between disabled children and their peers, which means that $62 \%$ of the articles addressed socialization as a secondary topic. The other objectives can be divided into describing the opinions on accessibility held by teachers, parents, or students (35\%), understanding the inclusion process (19\%), investigating the quality of life of adolescents with disabilities (4\%), and the attitudes of students without disabilities regarding inclusion $(4 \%)$.

Therefore, this literature review includes various aspects of the inclusion process beyond the issues of socialization. Nine publications explicitly reported on teachers', teachers' aides', and therapeutic assistants' beliefs that disabled students have limited learning potential (Brito, 2015; Bruno \& Lima, 2015; Campos \& Glat, 2016; Carvalho \& Nascimento, 2015; Ferreira et al., 2010) or reported that educational inclusion should occur only as part of a larger socialization program (Gomes \& Rey, 2007; Lemos et al., 2016; Souza et al., 2012; Vitta et al., 2010). The following statement by a teacher who participated in the study by Gomes and Rey (2007) excludes any possibility of academic development by a student with a disability: "He comes [to school] only to spend time with other kids; I mean, I guess he helps - he sweeps the classroom -, but there's no way he can learn" (Gomes \& Rey, 2007, p. 413).

Similarly, a participant in another study, a teacher's aide who works with students with disabilities in a municipal school district, suggests a belief that enabling socialization is the main responsibility of aides with the statement that ". . . our biggest role is to enable the socialization of these students within and outside the classroom" (Souza et al., 2012, p. 648).

The lack of adaptations to teaching methods imparted to teachers is a factor in cases of exclusion within supposedly inclusive educational contexts mentioned in six studies addressing simple behaviors such as speaking to or looking at students with hearing loss and DS (Campos \& Glat, 2016; Leandro et al., 2012), as well as more complex issues requiring professional training, such as changes to the curriculum and strategies that involve all students in a given activity (Angnes et al., 2016; 
Table 2

Summary of Articles Reviewed

\begin{tabular}{|c|c|c|c|c|}
\hline 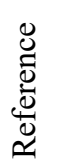 & 苞 & $\begin{array}{l}\stackrel{0}{0} \\
\frac{0}{0} \\
0\end{array}$ & 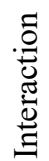 & 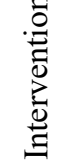 \\
\hline
\end{tabular}

$\begin{array}{lc}\begin{array}{l}\text { Gomes \& } \\ \text { Rey, 2007 }\end{array} & \begin{array}{c}\text { Educational inclusion and } \\ \text { shared experiences }\end{array} \\ \begin{array}{l}\text { Laplane } \\ \text { \& Batista, } \\ 2008\end{array} & \begin{array}{c}\text { Academic involvement } \\ \text { of children with low vision } \\ \text { and blindness in school }\end{array} \\ \begin{array}{l}\text { Teixeira \& } \\ \text { Kubo, 2008 }\end{array} & \begin{array}{r}\text { Interaction between students } \\ \text { syndrome (DS) }\end{array} \\ \begin{array}{l}\text { Anhão et al., } \\ \text { Social interactions involving } \\ \text { children with DS in early } \\ \text { childhood education }\end{array}\end{array}$

Ferreira et

al., 2010

Gomes \&

Mendes,

2010

Nascimento et al., 2010

Vitta et al., 2010

Mattos \& Nuernberg, 2011

Höher

Camargo \&

Bosa, 2012

Leandro et al., 2012

Souza et al., 2012

Chagas \&

Dias, 2014

Lemos et al., Social interactions involving
$2014 \quad$ children with an ASD at school 2014
Narratives on education, (auto) biographies, and accessibility

Educational inclusion in the do Sul State, Brazil

Students with special needs in general education
To explore the experiences shared by education professionals regarding the educational inclusion of students with special needs

U N

To discuss the development and learning of visually impaired children, their ways of understanding the world, and the use of resources to aid in their $\mathrm{N} \quad \mathrm{N}$ academic involvement

To characterize the interactions between students with DS and their classmates

$\mathrm{N} \quad \mathrm{N}$

To identify and analyze the social interactions between children with DS and children with typical development

Y N

To analyze teachers' beliefs regarding the importance of verbal language for the social interaction process

$\mathrm{N} \quad \mathrm{N}$

To characterize students with autism enrolled in general education in a specific city and to describe the way in which these students are being educated in general education classrooms

To present a study on the integration of disabled students through cooperative games

AI $\quad \mathrm{Y}$

To analyze teachers' perceptions of early childhood education in cases of children with disabilities between 3 and 6 years of age

To report an experience of psychoeducational intervention into a kindergarten class

AI Y

(1) to establish the social competence profile of a preschool child with autism compared to that of a typical child of the same age and gender; (2) to investigate the influence of the school environment (classroom or cafeteria) on the social competence of these children

Reflect on teachers' and students' thoughts about accessibility, on how teachers continue their own education, $\mathrm{N} N$ and on how students experience accessibility in practice

Reflect on the role of teacher's aids in the Paranaíba municipal education system

$\mathrm{U} \quad \mathrm{N}$

To evaluate teachers' knowledge on how to promote learning among students with some type of disability

U N
$\mathrm{Y} \quad \mathrm{N}$
To analyze autistic children's social interactions in the context of general education




\begin{tabular}{|c|c|c|c|}
\hline $\begin{array}{l}\text { Misquiatti } \\
\text { et al., } 2014\end{array}$ & $\begin{array}{l}\text { Communication } \\
\text { and ASD }\end{array}$ & $\begin{array}{l}\text { To analyze teachers' knowledge on the communication } \\
\text { involving people with autism spectrum disorders }\end{array}$ & $\mathrm{U}$ \\
\hline $\begin{array}{l}\text { Picolini \& } \\
\text { Maximino, } \\
2014\end{array}$ & $\begin{array}{l}\text { The process of inclusion } \\
\text { and social attitudes }\end{array}$ & $\begin{array}{c}\text { To determine social attitudes toward inclusion held } \\
\text { by students without disabilities before and after } \\
\text { a training and awareness program }\end{array}$ & $\mathrm{U}$ \\
\hline $\begin{array}{l}\text { Torres \& } \\
\text { Vieira, } 2014\end{array}$ & $\begin{array}{l}\text { Quality of life of adolescents } \\
\text { with disabilities }\end{array}$ & $\begin{array}{l}\text { To evaluate the perception of the quality of life } \\
\text { of disabled adolescents enrolled in school }\end{array}$ & $\mathrm{U}$ \\
\hline Brito, 2015 & $\begin{array}{l}\text { Inclusion of a child with an } \\
\text { ASD in an early childhood } \\
\text { education program }\end{array}$ & $\begin{array}{l}\text { To understand how social, educational, and } \\
\text { methodological relationships interact when an autistic } \\
\text { child is included in the general education classroom }\end{array}$ & $\mathrm{N}$ \\
\hline $\begin{array}{l}\text { Bruno \& } \\
\text { Lima, 2015 }\end{array}$ & $\begin{array}{l}\text { Communication with and } \\
\text { inclusion for the deaf Kaiowá } \\
\text { children in the family and } \\
\text { in the school system }\end{array}$ & $\begin{array}{c}\text { To investigate the methods used for communication } \\
\text { with and inclusion of deaf indigenous child } \\
\text { in the family and school system }\end{array}$ & $\mathrm{Y}$ \\
\hline $\begin{array}{l}\text { Carvalho \& } \\
\text { Nascimento, } \\
2015\end{array}$ & $\begin{array}{l}\text { Autistic children and their } \\
\text { inclusion in private schools }\end{array}$ & $\begin{array}{l}\text { To determine the ways in which autistic children } \\
\text { are included in private schools }\end{array}$ & $\mathrm{Y}$ \\
\hline $\begin{array}{l}\text { Angnes et } \\
\text { al., } 2016\end{array}$ & $\begin{array}{l}\text { A case study on the education } \\
\text { of a deaf student }\end{array}$ & $\begin{array}{c}\text { To investigate academic accessibility for deaf children } \\
\text { in the Brazilian city of Foz do Iguaçu }\end{array}$ & $\mathrm{N}$ \\
\hline $\begin{array}{l}\text { Campos \& } \\
\text { Glat, } 2016\end{array}$ & $\begin{array}{l}\text { Activities that aid } \\
\text { in the development } \\
\text { of a child with DS }\end{array}$ & $\begin{array}{l}\text { To investigate the learning process and teaching } \\
\text { practices in a report on a child with DS }\end{array}$ & AI \\
\hline $\begin{array}{l}\text { Lemos et al., } \\
2016\end{array}$ & $\begin{array}{l}\text { Parents' and teachers' } \\
\text { perceptions regarding } \\
\text { the inclusion of children } \\
\text { with an ASD }\end{array}$ & $\begin{array}{l}\text { To analyze parents' and teachers' perceptions regarding } \\
\text { autistic children and the academic accessibility process }\end{array}$ & $\mathrm{U}$ \\
\hline Oliva, 2016 & $\begin{array}{l}\text { Barriers to and resources } \\
\quad \text { for inclusion }\end{array}$ & $\begin{array}{c}\text { To investigate the quality of the accessibility } \\
\text { program offered to a visually impaired student enrolled } \\
\text { in a general education classroom }\end{array}$ & $\mathrm{Y}$ \\
\hline $\begin{array}{l}\text { Silva et al., } \\
2016\end{array}$ & $\begin{array}{l}\text { Relational approach between } \\
\text { families and inclusive schools }\end{array}$ & $\begin{array}{l}\text { Identify and describe partnerships between teachers } \\
\text { and the families of students with disabilities }\end{array}$ & $\mathrm{U}$ \\
\hline $\begin{array}{l}\text { Souza et al., } \\
2016\end{array}$ & $\begin{array}{l}\text { Social skills, social } \\
\text { interaction, } \\
\text { and inclusion }\end{array}$ & $\begin{array}{l}\text { (1) to analyze and characterize the repertoire of social } \\
\text { skills exhibited by a blind child; (2) to characterize } \\
\text { the social interaction of a blind child in the context } \\
\text { of inclusive education }\end{array}$ & $\mathrm{N}$ \\
\hline
\end{tabular}

Note. Key: Y-Yes; N-No; U-Information unknown; AI-Interaction considered only after intervention.

Campos \& Glat, 2016; Lemos et al., 2014; Oliva, 2016).

In $42 \%$ of the articles, there were reports of a lack of positive social interactions; in three of these articles, interventions were implemented to promote socialization (Campos \& Glat, 2016; Mattos \& Nuernberg, 2011; Nascimento et al., 2010). All of the other articles (Angnes et al., 2016; Brito, 2015; Ferreira et al., 2010; Gomes \& Mendes, 2010; Laplane \& Batista, 2008; Leandro et al., 2012; Souza et al., 2016), with one exception (Teixeira \& Kubo, 2008), described cases of complete exclusion in public and/or private schools in which children with disabilities did not participate in the proposed activities (academic or otherwise) and did not receive the changes to the curriculum and/or teaching methods necessary for the students to receive an equal opportunity in acquiring academic content.

In a study of the nature of the interactions between students with and without DS, Teixeira and Kubo (2008) performed a sociometric test with classrooms involving four students with 
DS, in which each student was asked to list three names in each category to describe other students who were friends, students who were not friends, students whom they expected would go to college, and students whom they expected would not go to college. The authors found that, even with the students with DS participating in the same activities and exhibiting a level of academic performance similar to that of the other students in the class, their peers reported negative expectations regarding the DS students' likelihood to attend college.

In addition, only $19 \%$ of the studies considered exhibited examples of spontaneous socialization (with no intervention on the part of the researchers to encourage it; Anhão et al., 2010; Bruno \& Lima, 2015; Carvalho \& Nascimento, 2015; Höher Camargo \& Bosa, 2012; Oliva, 2016). These studies included the survey given to therapeutic assistants working with ASD children in early childhood education; in the study in question, the cases of socialization were reported by the adult professionals (Carvalho \& Nascimento, 2015). For this reason, the report offers less reliability, since it is not based on concrete data or researchers' observations of interactions.

A study that reported positive interactions involved a deaf child from an indigenous tribe who participated in games with peers; however, communication was limited since the child did not know Brazilian sign language (LIBRAS) - the child only knew the signs used to communicate simple concepts, such as hunger, swimming in the river, school, and animal (Bruno \& Lima, 2015). Though the case study by Oliva (2016) reported that socialization of a visually impaired student was not hindered, the conclusions of the paper note that the student "is accepted, but is less valued" (Oliva, 2016, p. 500). The author explains that the student herself felt inferior to her typical peers and did not respond to interactions with these peers with the same intensity with which she responded to other special needs students. These studies describe interactions and games among peers; however, the results of the research demonstrate the limitations and hindrances to these interactions becoming reciprocal friendships. In terms of barriers to inclusion, the authors considered herein often highlight the lack of proper teacher training, the need for adaptations to teaching materials, and the beliefs held by teachers and other staff regarding the extent to which special needs children can truly learn academic content.

Some of the studies identified interactions between disabled children and their peers through comparisons between their levels of social performance. In one study, there were no significant differences in most of the behaviors considered relevant, with the exception of some of the items within a sociability/cooperation and social assertion category, in which children with ASDs achieved lower scores (Höher Camargo \& Bosa, 2012). In another study, there were differences in imitation behavior (which was more common among children with DS) and in the tendency to establish the first contact with a peer, which was more common among children without DS (Anhão et al., 2010). These two studies were both performed with children in early childhood education, and the authors concluded that the social development of children with DS is similar to that of children without DS, a result that indicates that early accessibility and inclusion programs provide benefits for students.

Lemos et al. (2014) also studied social interactions involving children with ASDs in early childhood education; however, they focused on teacher behavior in the encouragement of social development. The authors reported that the most common behaviors exhibited by teachers (language-based instructions and physical support) are not as effective at establishing strategies that contribute to improving students' social skills as strategies such as observation, demonstrating affection, and modeling, all of which occurred less frequently.

\section{Interventions Reported}

Only $19 \%$ of the analyzed articles presented interventions that sought to promote the socialization of children with disabilities. One report on an intervention for a student with an ASD was found (Mattos \& Nuernberg, 2011), while one study presented an intervention 
involving non-disabled peers (Picolini \& Maximino, 2014), one involved the entire class (Nascimento et al., 2010), and two of the studies presented interventions involving teachers (Campos \& Glat, 2016; Misquiatti et al., 2014).

Mattos and Nuernberg (2011) developed an alternative mode of communication that made abstract messages into something concrete and visible. Cards were created with pictures and written descriptions of everyday situations, such as brushing teeth and washing hands. With the help of the teacher and the researchers, students also made puppets representing each of the students of the class, as well as miniature playground equipment to simulate the games played during recess. The authors concluded that the intervention was effective, since it encouraged social involvement through play. However, no pre- or post-intervention measures were taken to allow for a quantitative data analysis.

In the article by Picolini and Maximino (2014), a Likert Scale of Social Attitudes Regarding Inclusion was applied as a pre- and post-intervention measure. The authors argue that typical peers' attitudes are extremely relevant for the extent of inclusion that will occur in a given context. They created and applied a training program on genetic syndromes and accessibility to students without disabilities. The programs lasted an average of three months and were divided into three stages, which included an in-person stage consisting of lecture-style classes; a password-accessible, month-long distance-learning activity in which a tutor was made available online; and a practical class in which typical students engaged with people with genetic syndromes, their relatives, and educators. Since the scores on the scale were significantly higher after the intervention, the authors concluded that the training program was effective in promoting attitudes that favored inclusion and accessibility.

The study by Nascimento et al. (2010) highlighted the importance of collaborative play in promoting the integration of disabled children into the class. The authors made participatory observations and recorded them in field notebooks. After students refused to interact with disabled peers, the researchers initiated a series of collaborative games that encouraged closer interaction between disabled students and typical peers. The activities included a dancing game involving balloons and another cooperative dancing game involving chairs. The authors confirmed that the games were effective in increasing interaction between children with and without disabilities. Their observations in their field notebooks were used as evidence of the effectiveness.

Another study implemented an informative intervention regarding communication with children with ASDs (Misquiatti et al., 2014). The authors worked off the assumption that wellinformed teachers would be better equipped to promote inclusion and interactions between children with ASDs and typical children. The authors gave the teachers a pre- and postintervention questionnaire, resulting in better scores after the intervention. The applied intervention consisted of 4 four-hour class-style meetings in which each teacher also received a manual about ASDs. It is important to note that in both the study that trained teachers (Misquiatti et al., 2014) and the study that trained typical students (Picolini \& Maximino, 2014), the authors based their conclusions on the results of written tests and not on concrete effects observed in daily classroom activities after the interventions. For this reason, the efficacy of these interventions may be better understood as their ability to change the conversation about educational inclusion than their ability to change actions within an educational context.

In the action research performed by Campos and Glat (2016), the interventions encouraged the participation of a child with DS in daily early childhood education activities and in social interactions with peers. The teacher received instructions on how to reconsider her practices, which had included giving the child with DS a snack before snack time and attributing certain behaviors exhibited by the child with DS as the result of the fact that she was "just a baby" when talking to the other students (despite the fact that the child with DS was two years older than the other children). The teacher was also informed of 
behaviors that would encourage the development of the child with DS, as well as of ways in which she could explain instructions to the child with DS. The efficacy of the interventions was based on the student's progress, as well as on changes in the other students in the class. The student with DS was able to eat her snack without help, put away the colored pencils after using them, and play and maintain conversations with her peers, who began to call her by her name.

All of the interventions reported in these students were described as effective; however, some caveats exist. The lack of concrete data to identify the occurrence of positive social interactions makes it difficult to establish the situations encountered before the interventions and the extent of the changes exhibited after the interventions. Furthermore, the descriptions were often unclear and subjective, and the activities performed do not lend themselves to reproducibility (Campos \& Glat, 2016; Mattos \& Nuernberg, 2011; Nascimento et al., 2010).

\section{Final Comments}

Research into social interactions in accessibility and inclusion programs in the last decade has been performed by professionals from various fields, a positive factor given the interdisciplinary nature of education. However, there is a substantial difference between research that merely describes situations and research that creates interventions or strategies, puts them into practice, and evaluates their effects on social interactions and on changing pre-intervention situations.

In any case, when taken together, the vast amount of literature involving surveys, case studies, and other types of descriptive research in several different Brazilian states, and involving children at different educational stages and with different disabilities suggests that educational inclusion in Brazilian public and private schools still faces barriers to success. The barriers observed in the studies considered herein include invisibility, exclusion, and the negligence of disabled students and their true educational needs. There are few reports in which social interactions between disabled children and their peers are not hindered (Bruno \& Lima, 2015; Carvalho \& Nascimento, 2015; Oliva, 2016), and, even in these cases, the disabled children were found to be delayed academically; in other words, there was evidence of inclusion only in terms of socialization.

It is important to highlight the need for research into how to address exclusion within inclusive education contexts, which strategies to use, which variables are affecting this process, and how to change it. Other discussions on improving the learning of academic content, though also pertinent and urgent, are outside the scope of this literature review.

In conclusion, the low number of experimental and intervention-based studies on social interactions in the context of educational inclusion may be the result of the difficulty in performing field research on this topic, a difficulty that is compounded by the need to study a specific population. Nevertheless, this type of research is extremely relevant not only for increasing knowledge on this topic, but, more importantly, because of the implications that discoveries in this field will have on the efficacy of educational inclusion.

\section{References}

Angnes, J. S., Morás, N. A. B., Klozovski, M. L., \& Reali, K. M. (2016). Um estudo sobre a educação do sujeito surdo na rede estadual de educação de Foz do Iguaçu-Paraná. HOLOS, 8, 338-354. Retrieved from http://www2.ifrn.edu.br/ojs/ index.php/HOLOS/article/download/4248/pdf

Anhão, P. P. G., Pfeifer, L. I., \& Santos, J. L. D. (2010). Interação social de crianças com Síndrome de Down na educação infantil. Revista Brasileira de Educação Especial, 16(1), 31-46. Retrieved from http://www.producao.usp.br/ handle/BDPI/7744

Anísio Teixeira Institute for Educational Research and Studies. (2008). Sinopse estatística da Educação Básica 2007. Brasília, DF: Author.

Anísio Teixeira Institute for Educational Research and Studies. (2014). Censo Escolar da Educação Básica 2014: Resumo técnico. Brasília, DF: Author. 
Anísio Teixeira Institute for Educational Research and Studies, \& Brazilian Ministry of Education and Culture. (2017). Censo Escolar da Educação Básica 2016: Notas estatísticas. Brasília, DF: Brazilian Ministry of Education and Culture.

Bandeira, M., Del Prette. Z. A. P., Del Prette, A. \& Magalhães, T. (2009). Validação das Escalas de Habilidades Sociais, Comportamentos Problemáticos e Competência Acadêmica (SSRS-BR) para ensino fundamental. Psicologia: Teoria e Pesquisa, 25(2), 271-282. Retrieved from http://www.scielo.br/pdf/ptp/ v25n2/a16v25n2

Batista, M. W., \& Enumo, S. R. F. (2004). Inclusão escolar e deficiência mental: Análise da interação social entre companheiros. Estudos de Psicologia (Natal), 9(1), 101-111. http://dx.doi. org/10.1590/S1413-294X2004000100012

Baer, D. M., \& Wolf, M. M. (1970). The entry into natural communities of reinforcement. In $\mathrm{R}$. Ulrich, T. Stachnick, \& J. Mabry (Eds.), Control of human behavior (pp. 319-324). Glenview, IL: Scott \& Foresman. Retrieved from https://files. eric.ed.gov/fulltext/ED020533.pdf

Brazilian Ministry of Education and Culture. (2008). Política Nacional da Educação Especial na Perspectiva da Educação Inclusiva. Brasília, DF: Author.

Brito, E. R. D. (2015). A inclusão do autista a partir da educação infantil: Um estudo de caso em uma pré-escola e em uma escola pública no município de Sinop-Mato Grosso. Eventos Pedagógicos, 6(2), 82-91. Retrieved from http://sinop.unemat. br/projetos/revista/index.php/eventos/article/ view/1873/1422

Bruno, M. M. G., \& Lima, J. M. S. (2015). As formas de comunicação e de inclusão da criança Kaiowá surda na família e na escola: Um estudo etnográfico. Revista Brasileira de Educação Especial, 21(1), 127-142. http://dx.doi. org/10.1590/S1413-65382115000100009

Campos, K., \& Glat, R. (2016). Procedimentos favoráveis ao desenvolvimento de uma criança com Síndrome de Down numa classe comum. Revista Educação Especial, 29(54). http:// dx.doi.org/10.5902/1984686X10399

Carvalho, B. S., \& Nascimento, L. (2015). O autista e sua inclusão nas escolas particulares da cidade de Teresina-PI. Revista Educação Especial, 28(53). http://dx.doi.org/10.5902/1984686X17327.
Chagas, M., \& Dias, F. (2014). Alunos com necessidades educacionais especiais nas escolas regulares de Mossoró-RN. HOLOS, 5(30). doi: 10.15628/holos.2014.968

Del Prette, Z. A. P., \& Del Prette, A. (2005). Psicologia das habilidades sociais na infância: Teoria e prática. Petrópolis, RJ: Vozes.

Del Prette, Z. A. P., Del Prette, A., De Oliveira, L. A., Gresham, F. M., \& Vance, M. J. (2012). Role of social performance in predicting learning problems: Prediction of risk using logistic regression analysis. School Psychology International, 33(6), 615-630. doi: 10.1177/0020715211430373

Dias, A. C. G., Patias, N. P., \& Abaid, J. L.W. (2014). Psicologia Escolar e possibilidades na atuação do psicólogo: Algumas reflexões. Psicologia Escolar e Educacional, 18(1). Retrieved from http://www.redalyc.org/articulo. oa? id $=282330520011$

Dias, P., Sousa, J., Gonçalves, M., Flores, P., \& Pérez, J. D. (2016). Atitudes dos pares sobre a inclusão: Contributos da adaptação de um instrumento. Revista da Associação Portuguesa de Psicologia, 30(2), 95-106. http://dx.doi. org/10.17575/rpsicol.v30i2.1099

DiPerna, J. C. (2006). Academic enablers and student achievement: Implications for assessment and intervention services in the schools. Psychology in the Schools, 43(1), 7-17. doi: 10.1002/ pits. 20125

Ferreira, D. R., Ferreira, W. D. A., \& Oliveira, M. S. (2010). Pensamento e linguagem em crianças com síndrome de Down: Um estudo de caso da concepção das professoras. Ciências \& Cognição, 15(2), 216-227. Retrieved from http:// pepsic.bvsalud.org/pdf/cc/v15n2/v15n2a19.pdf

Ferreira, M. A. G. (2017). Teacher-child interactions disability profile and social experiences of children in inclusive preschool classrooms (Doctoral dissertation, ISPA-Instituto Universitário, Lisboa, Portugal). Retrieved from http://repositorio.ispa.pt/handle/10400.12/5487

Garces, S. B. B. (2010, April). Classificação $e$ Tipos de Pesquisas [Monograph]. Cruz Alta, RS: Unicruz. Retrieved from http:// www.redepoc.com/jovensinovadores/ ClassificacaoeTiposdePesquisas.doc

Garcia, J. (2012). O futuro das práticas de interdisciplinaridade na escola. Revista 
Diálogo Educacional, 12(35), 209-230. Retrieved from http://www.redalyc.org/ html/1891/189123706011/

Gomes, C., \& Rey, F. L. G. (2007). Inclusão escolar: Representações compartilhadas de profissionais da educação acerca da inclusão escolar. Psicologia Ciência e Profissão, 27(3). Retrieved from http://www.scielo.br/pdf/pcp/ v27n3/v27n3a04

Gomes, C. G. S., \& Mendes, E. G. (2010). Escolarização inclusiva de alunos com autismo na rede municipal de ensino de Belo Horizonte. Revista Brasileira de Educação Especial, 16(3), 375-396. Retrieved from http://hdl.handle. net/10183/36509

Höher Camargo, S. H., \& Bosa, C. A. (2012). Competência social, inclusão escolar e autismo: Um estudo de caso comparativo. Psicologia: Teoria e Pesquisa, 28(3), 315-324. Retrieved from https://revistaptp.unb.br/index.php/ptp/ article/view/217/530

Laplane, A. L. F. D., \& Batista, C. G. (2008). Ver, não ver e aprender: A participação de crianças com baixa visão e cegueira na escola. Cadernos Cedes, 8(75), 209-227. Retrieved from https://s3.amazonaws.com/academia.edu. documents/33231853/v28n75a05.pdf?AWS AccessKeyId=AKIAIWOWYYGZ2Y53UL $3 \mathrm{~A} \&$ Expires $=1509822285 \&$ Signature $=$ PId 8 kdrzw\%2FbPynxy8\%2F5IBxHXNyk\%3D\&r esponse-content-disposition $=$ inline $\% 3 \mathrm{~B} \% 20$ filename\%3DVer_nao_ver_e_aprender_a_ participacao_de.pdf

Law No. 12,764. (2012, December 28). Institui a Política Nacional de Proteção dos Direitos da Pessoa com Transtorno do Espectro Autista; e altera o $\S 30$ do art. 98 da Lei no 8.112, de 11 de dezembro de 1990. Diário Oficial da União. Retrieved from http://www.planalto.gov.br/ ccivil_03/_ato2011-2014/2012/lei/112764.htm

Leandro, A. L., Costa, M. A. C., \& Aquino, S. S. (2012). Narrativas de formação,(auto) biografia e inclusão: Experiências de professores e alunos no ensino médio. HOLOS, 2. Retrieved from http:// www.redalyc.org/articulo.oa? $\mathrm{id}=481549265019$

Lemos, E. L. M. D., Salomão, N. M. R., \& AgripinoRamos, C. S. (2014). Inclusão de crianças autistas: Um estudo sobre interações sociais no contexto escolar. Revista Brasileira de Educação Especial, 20(1), 117-130. Retrieved from https:// www.researchgate.net/profile/Nadia_Maria_
Salomao/publication/288107335_Inclusion of_children_with_autism_A_study_of_social_ interactions_within_the_school_context/ links/56aa158208ae7f592f0f1a32/Inclusionof-children-with-autism-A-study-of-socialinteractions-within-the-school-context.pdf

Lemos, E. L. M. D., Salomão, N. M. R., Aquino, F. S. B., \& Agripino-Ramos, C. S. (2016). Concepções de pais e professores sobre a inclusão de crianças autistas. Fractal: Revista de Psicologia, 28(3), 351-361. http://dx.doi. org/10.1590/1984-0292/1229

Mattos, L. K., \& Nuernberg, A. H. (2011). Reflexões sobre a inclusão escolar de uma criança com diagnóstico de autismo na educação infantil. Revista Educação Especial, 24(39). http:// dx.doi.org/10.5902/1984686X1989

Mendes, E. G. (Ed.). (2015). A escola e a inclusão social na perspectiva da educação especial. São Carlos, SP: Universidade Federal de São Carlos. Retrieved from http://livresaber.sead.ufscar. br:8080/jspui/bitstream/123456789/2651/1/Pe_ Eniceia_EducacaoEspecial.pdf

Misquiatti, A. R. N., Brito, M. C., dos Santos Ceron, J., Piassi Carboni, P., \& Olivati, A. G. (2014). Comunicação e transtornos do espectro do autismo: Análise do conhecimento de professores em fases pré e pós-intervenção. Revista CEFAC, 16(2). Retrieved from http:// www.redalyc.org/articulo.oa?id=169331137015

Nascimento, G. S., de Moura Scapim, K. C., \& Silveira, C. A. B. (2010). Inclusão escolar e jogos cooperativos: Uma possibilidade de atuação do psicólogo escolar no processo de socialização e integração. Revista da SPAGESP, 11(2). Retrieved from https://search.proquest. com/openview/9e4471a2594f211290bbd26c2e 43dd82/1 ?pq-origsite $=$ gscholar\&cbl $=2030189$

O’Connor, R. D. (1969). Modification of social withdrawal through symbolic modeling. Journal of Applied Behavior Analysis, 2(1), 15-22. doi: 10.1901/jaba.1969.2-15

O'Connor, R. D. (1972). Relative efficacy of modeling, shaping, and the combined procedures for modification of social withdrawal. Journal of Abnormal Psychology, 79(3), 327-334. http:// dx.doi.org/10.1037/h0033226

Oliva, D. V. (2016). Barreiras e recursos à aprendizagem e à participação de alunos em situação de inclusão. Psicologia USP, 27(3). http://dx.doi.org/10.1590/0103-656420140099 
Picolini, M. M., \& Maximino, L. P. (2014) Programa de capacitação em síndromes genéticas: $O$ processo de inclusão e as atitudes sociais. Revista CEFAC, 16(6), 1871-1877. Retrieved from http://www.redalyc.org/articulo. oa?id=169339740015

Ribeiro, S. L. (2016). Violência simbólica: Impactos à inclusão escolar. Journal of Research in Special Educational Needs, 16, 1095-1098. doi: 10.1111/1471-3802.12255

Rosin-Pinola, A. R., \& Del Prette, Z. A. P. (2014). Inclusão escolar, formação deprofessores e a assessoria baseada em habilidades sociais educativas. Revista Brasileira de Educação Especial, 20(3), 341-356. http://dx.doi. org/10.1590/S1413-65382014000300003

Santo, A. E., \& Santos, M. T. (2016). A inclusão escolar de alunos com multideficiência. Journal of Research in Special Educacional Needs, 16(1), 89-93. doi: 10.1111/1471-3802.12272

Silva, A. M., Cabral, L. S. A., \& Martins, M. D. F. A. (2016). Abordagem relacional entre família e escola inclusiva sob as perspectivas de professores. Interfaces da Educação, 7(19), 191-205. Retrieved from http://periodicos.uems br/index.php/interfaces/article/view/1065

Souza, A. C., Bezerra, G. F., Bezerra, M. F., do Nascimento Costa, P., \& Nozu, W. C. S. (2012). A inclusão escolar no município de Parnaíba (MS): Reflexões sobre a atuação profissional do monitor de alunos com deficiência. Revista Pedagógica, 14(29), 635-664. http://dx.doi. org/10.22196/rp.v14i29.1467.

Souza, M. P., Silva, P. A. B., França-Freitas, M. L. P., \& Gatto, G. M. S. (2016). Habilidades sociais, interação social e a inclusão de uma criança cega. Revista Educação Especial, 29(55), 323336. Retrieved from http://www.redalyc.org/ articulo.oa? $\mathrm{id}=313146769006$
Teixeira, F. C., \& Kubo, O. M. (2008). Características das interações entre alunos com Síndrome de Down e seus colegas de turma no sistema regular de ensino. Revista Brasileira de Educação Especial, 14(1), 75-92.

Torres, V. M. F., \& Vieira, S. C. M. (2014). Qualidade de vida em adolescentes com deficiência. Revista CEFAC, 26(6), 1953-1961. Retrieved from http://www.redalyc.org/articulo. oa?id=169339740024

United Nations Educational, Scientific and Cultural Organization. (1990). World Conference on Education for All/Declaração Mundial sobre Educação para Todos: Satisfação das necessidades básicas de aprendizagem (ED/90/ CONF/205/1). Jomtien, Thailand: Author. Retrieved from http://unesdoc.unesco.org/ images/0008/000862/086291por.pdf

United Nations Educational, Scientific and Cultural Organization, Office Brasilia. (1994). World Conference on Special Needs Education: Access and Quality/Declaração de Salamanca sobre Princípios, Política e Práticas na Area das Necessidades Educativas Especiais (BR/1998/PI/H/7). Salamanca, Spain: Author. Retrieved from http://unesdoc.unesco.org/ images/0013/001393/139394por.pdf

Vitta, F. C. F. D., Vitta, A. D., \& Monteiro, A. S. (2010). Percepção de professores de educação infantil sobre a inclusão da criança com deficiência. Revista Brasileira de Educação Especial, 16(3) 415-428. Retrieved from http:// hdl.handle.net/11449/30127

Received: 06/03/2018

$1^{\text {st }}$ revision: $27 / 05 / 2018$

$2^{\text {nd }}$ revision: 07/06/2018

Accepted: 08/06/2018

(cc)BY (C) The Author(s), 2018. Open Access. This article is distributed under the terms of the Creative Commons Attribution 4.0 International License (http://creativecommons.org/licenses/by/4.0/), which permits unrestricted use, distribution, and reproduction in any medium, provided you give appropriate credit to the original author(s) and the source, provide a link to the Creative Commons license, and indicate if changes were made. 